\title{
Identification of spleen tyrosine kinase as a potential therapeutic target for esophageal squamous cell carcinoma using reverse phase protein arrays
}

\author{
Mustafa A. Barbhuiya ${ }^{1,2}$, Manoj K. Kashyap ${ }^{3}$, Vinuth N. Puttamallesh ${ }^{4,5}$, Rekha \\ Vijay Kumar ${ }^{6}$, Xinyan Wu ${ }^{1}$, Akhilesh Pandey ${ }^{1,2,4,7,8,9,10}$ and Harsha Gowda ${ }^{4,10}$ \\ ${ }^{1}$ McKusick-Nathans Institute of Genetic Medicine, Johns Hopkins University School of Medicine, Baltimore, MD, USA \\ ${ }^{2}$ Sidney Kimmel Comprehensive Cancer Centre, Johns Hopkins University School of Medicine, Baltimore, MD, USA \\ ${ }^{3}$ School of Life and Allied Health Sciences, Glocal University, Saharanpur, India \\ ${ }^{4}$ Institute of Bioinformatics, International Technology Park, Bangalore, India \\ ${ }^{5}$ Amrita School of Biotechnology, Amrita Vishwa Vidyapeetham, Kollam, India \\ ${ }^{6}$ Department of Pathology, Kidwai Memorial Institute of Oncology, Bangalore, India \\ ${ }^{7}$ Department of Biological Chemistry, Johns Hopkins University School of Medicine, Baltimore, Maryland, USA \\ ${ }^{8}$ Department of Oncology, Johns Hopkins University School of Medicine, Baltimore, Maryland, USA \\ ${ }^{9}$ Department of Pathology, Johns Hopkins University School of Medicine, Baltimore, Maryland, USA \\ ${ }^{10}$ Manipal Academy of Higher Education (MAHE), Manipal, India \\ Correspondence to: Harsha Gowda, email: harsha@ibioinformatics.org \\ Akhilesh Pandey, email: pandey@jhmi.edu \\ Keywords: ESCC; SYK; entospletinib; RPPA
}

Received: August 31, $2017 \quad$ Accepted: March 06, $2018 \quad$ Published: April 06, 2018

Copyright: Barbhuiya et al. This is an open-access article distributed under the terms of the Creative Commons Attribution License 3.0 (CC BY 3.0), which permits unrestricted use, distribution, and reproduction in any medium, provided the original author and source are credited.

\section{ABSTRACT}

The vast majority of esophageal cancers in China, India and Iran are esophageal squamous cell carcinomas (ESCC). A timely diagnosis provides surgical removal as the main therapeutic option for patients with ESCC. Currently, there are no targeted therapies available for ESCC. We carried out reverse phase protein array-based protein expression profiling of seven ESCC-derivedcell lines and a non-neoplastic esophageal epithelial cell line (Het-1A) to identify differentially expressed proteins in ESCC. SYK non-receptortyrosine kinase was overexpressed in six out of seven ESCC cell lines that were used in the study. We evaluated the role of SYK in ESCC using the pharmacological inhibitor entospletinib (GS-9973) and siRNA-based knock down studies. Entospletinib is a selective inhibitor of SYK, which is currently being evaluated in phase II clinical trials for hematological malignancies. Using in vivo subcutaneous tumor xenografts in mice, we demonstrate that treatment with entospletinib significantly inhibits tumor growth. Further clinical studies are needed to prove the efficacy of entospletinib as a targeted therapeutic agent for treating ESCC.

\section{INTRODUCTION}

The cancers of esophagus are mainly of two types - esophageal adenocarcinoma (EAD) and esophageal squamous cell carcinoma (ESCC). Esophageal cancer is the eighth most commonly occurring cancer and the sixth leading cause of cancer deaths worldwide [1]. In contrast to EAD, ESCC is more common in developing countries including India, China, and Iran $[1,2]$. The incidence of ESCC is more common in males, with the male: female ratio being 2:1. Approximately $83 \%$ of total incidence of ESCC and $86 \%$ of deaths occur in developing countries [2]. The five-year survival rate is only $10-17 \%$ [3]. The major risk factors associated with ESCC include tobacco, alcohol, red meat, hot drinks, poor oral hygiene, ingestion of mycotoxins, salted food, smoked foods, and deficiency 
of essential micronutrients such as vitamin A and zinc, genetics and conditions like Plummer-Vinson/PattersonKelly syndrome [4-7]. Genomics and proteomics approaches have previously been used to explore molecular alterations associated with $\operatorname{ESCC}[1,4,8,9]$.

Reverse phase protein arrays (RPPAs) have emerged as a non-mass spectrometry based high-throughput platform to carry out proteomic profiling studies. They have been used to identify potential biomarkers using biofluids, cell and tissue lysates. In recent years, RPPA has been utilized for profiling breast cancers [10], endometrioid and clear cell carcinomas [11] head and neck squamous cell carcinoma (HNSCC) patient derived xenografts, [12] studying mTOR activation in sorafenibresistant hepatocellular carcinoma (HCC) [13], for biomarker discovery [14], characterization of signaling pathways [15] and for distinguishing different cancers [16]. We used RPPA for profiling ESCC cell lines to identify differentially expressed proteins in ESCC. We further validated SYK as a potential therapeutic target using in vitro and in vivo models through genetic and pharmacological inhibition of the target.

\section{RESULTS}

Differentially expressed proteins in ESCC cell lines

Protein expression profiling of a panel of ESCC cell lines and Het-1A, a non-neoplastic esophageal epithelial cell line was carried out using RPPA (Figure 1). This led to identification of several proteins that were differentially expressed in ESCC cell lines as compared to Het-1A (Supplementary Table 1). These differentially expressed proteins included caveolin 1 (CAV1), cadherin 1 (CDH1), claudin 7 (CLDN7), cadherin 3 (CDH3), and PAR proteins, which were all 2-fold overexpressed in ESCC cell lines as compared to Het-1A cells (Supplementary Figure 1). SYK protein was overexpressed more than 3-fold in five of the seven cell lines (TE1, TE2, TE5, TE11 and TE15) (Figure 2A, 2B) and X-fold in the sixth cell line (you say overexpressed in 6 out of 7 cell lines!!!). CAV1, one of the three members of caveolin family, is a $21 \mathrm{kDa}$ scaffoldingprotein that has been implicated in tumorigenesis and metastasis and involved in different

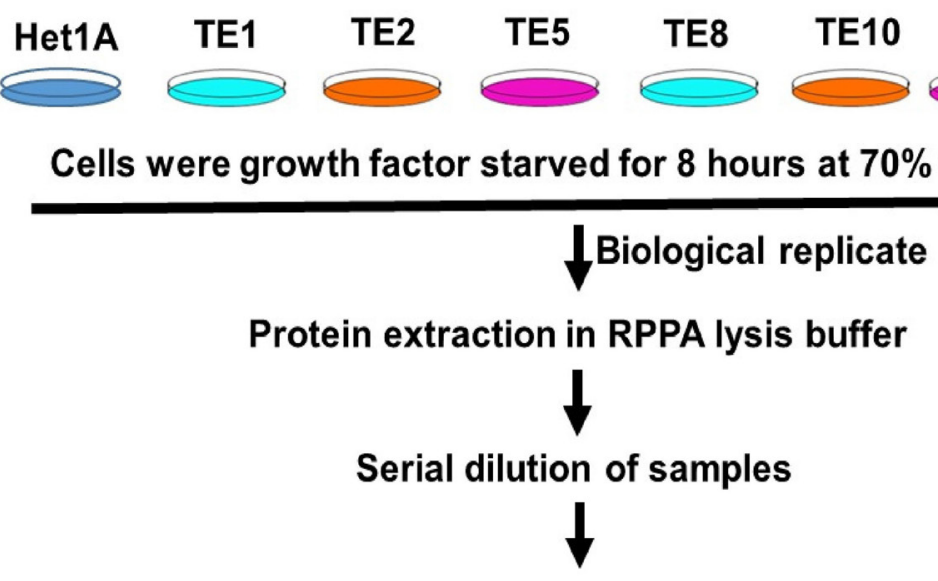

Array samples on nitrocellulose coated slides

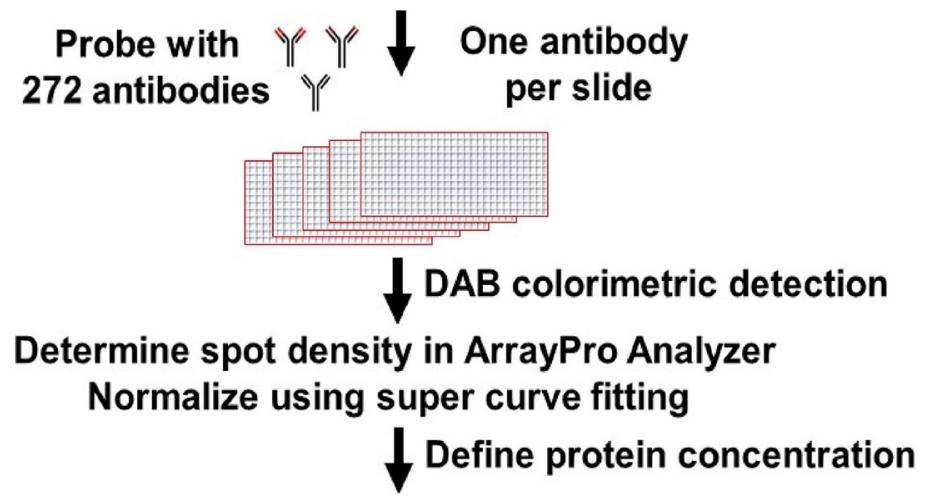
Identification of differentially expressed proteins in ESCC cell lines compared to Het1A cell line

Figure 1: Experimental workflow followed for carrying out RPPA based protein expression profiling. 
cellular pathways including endocytosis, lipid homeostasis and signal transduction $[17,18]$. In a number of cancer types including ovarian [19], colon [20] and breast cancer [21], CAV1 was found to be downregulated. In contrast, there are also number of malignancies where CAV1 was found to be overexpressed e.g. pancreatic adenocarcinoma $[18,22]$, prostate cancer [22, 23], non-small cell lung carcinoma, renal cell carcinoma (RCC) and glioblastoma [17]. In our study, we found that CAV1 was overexpressed in ESCC cell lines, which was in agreement with previous studies on CAV1 in ESCC [24-26].

Expression of claudins is known to be dysregulated in different cancers including HNSCC [27] breast cancer [28] ovarian [29] and gastric cancer [30]. In our study, we observed $>2$-fold change in CLDN7 expression in all the TE-series cell lines except TE8. The undetectable levels of CLDN7 in TE8 cell line is in agreement with a previous study on ESCC cell line where CLDN7 was found to be expressed in TE1, TE2, and TE11 but not in TE8 cell line [31]. CLDN7 shows difference in expression pattern between ESCC cell lines and surgically resected ESCC tissue samples. We and others observed expression of CLDN7 in TEseries ESCC cell lines, but expression of CLDN7 was found to be downregulated in ESCC tissue sections as compared with primary esophageal keratinocytes [31]. This study using 3-D cultures showed that the CLDN7 expression is dependent on the microenvironment of the tissue, thus observations of CLDN7 in the homogeneous population of TE cell lines may not reflect the outcome of tumor-microenvironment interaction [31]. Decrease in expression of CLDN7 protein has been reported in ESCC as compared to the prickle layer of the normal esophageal squamous epithelium [32].

\section{SYK is overexpressed in most ESCC cell lines}

SYK was overexpressed $>2$-fold in 6 out of 7 ESCC cell lines as compared to normal esophageal epithelial cell line (Figure 2A, 2B). We used TE8 (SYK negative) and TE11 (SYK positive) lines for functional studies using siRNA based silencing of SYK. We screened for SYK expression by semi-quantitative reverse transcriptase PCR and observed high expression in TE11 cell line but could not detect expression in normal Het-1A and TE8 cells (Figure 2C). In recent years, there have been extensive studies focused on SYK, which is a nonreceptor tyrosine kinase. SYK consists of a tyrosine kinase domain, two adjacent src homology (SH2) domains, but no SH3 domain [33]. SYK is a $72 \mathrm{kDa}$ protein containing 635 amino acids and encoded by a gene located on chromosome 9q22 [33]. SYK is known to play a role in tumor invasion and progression and migration depending on the cell type [34-36]. SYK expression has been reported in B, T and NK cells and it is an integral part of BCR signaling of B cell precursors as well as mature B lymphocytes [37]. SYK is an upstream regulator of PI3K in BCR signaling pathway. SYK has the ability to activate PI3K by using adaptor proteins like CBL, GRB2 or CD19. Overall, SYK regulates anti-apoptotic mammalian target of rapamycin (mTOR), NF $\kappa \mathrm{B}$, and STAT3 pathways $[37,38]$. Overexpression of SYK has been reported in anaplastic lymphoma kinase positive tumors. Constitutive activation of SYK and BCR signaling is essential for cell proliferation and survival in different B-cell malignancies [39-41]. Inhibition of SYK has shown promising results in Hodgkin lymphoma and leukemia [41]. SYK expression was studied in HNSCC and 6 out of 10 cell lines were found to be SYK-positive. In addition, HNSCC samples

\section{A}
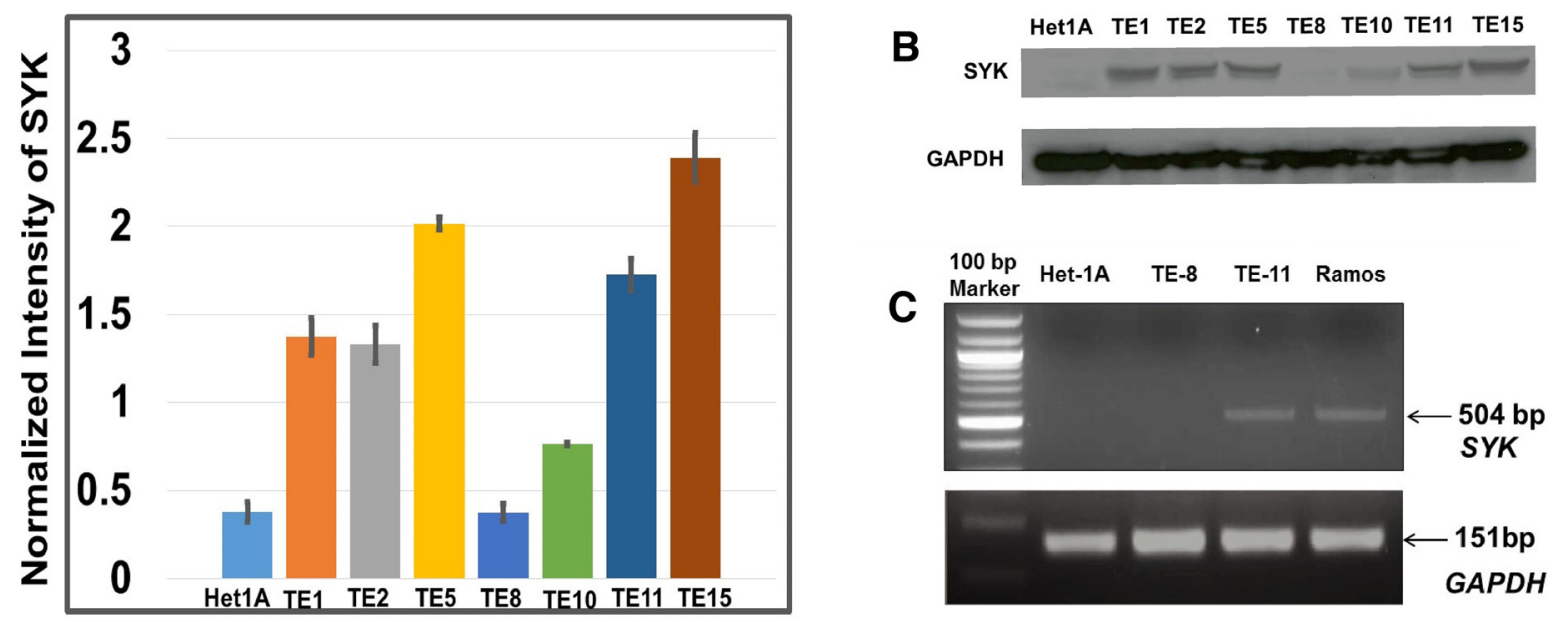

Figure 2: Expression of SYK across ESCC cell lines and non-neoplastic esophageal epithelial cell line. (A) Histogram showing expression of SYK in ESCC cell lines as determined by RPPA array. (B) Expression of SYK across ESCC cell lines by Western blotting. (C) RT-PCR based evaluation of SYK expression in TE8, TE11 and Ramos cell lines. Ramos cell line was used as positive control. 
from a Thai population showed higher SYK expression in lymph nodes as compared to HNSCC tumors and adjacent normal tissues. A significant correlation was found between expression of SYK and recurrence of the disease in HNSCC patients [42].

In our study, we observed SYK expression in all TEseries ESCC cell lines except TE-8. Expression of SYK was also not detectable in non-neoplastic esophageal epithelial cell line Het-1A. Recently, SYK overexpression has been reported in triple negative breast cancers and ovarian cancer. SYK has been suggested as a potential druggable target for a subset of triple negative breast cancers [43]. We evaluated the effect of inhibiting SYK in ESCC cell lines. SYK acts as a tumor suppressor in pancreatic adenocarcinoma and regulates cellular growth and invasion [44]. There is a great variation in the expression of SYK in epithelial cancers including breast and HNSCC [42].

Since SYK provides a pro-survival signal and it can modulate tumorigenesis via epithelial-mesenchymal transition, it could serve as a therapeutic target in cancers [45]. Indeed, SYK has been a target of interest in B cell acute lymphoblastic leukemia [46] and lymphomas [47].
SYK inhibitors including fostamatinib and BAY61-3606 have been reported to reduce growth of B-ALL in vitro [46]. Interestingly, a combination of PI3 kinase inhibitor (idelalisib, GS-1101) and SYK inhibitor (fostabatinib) reduced the survival of CLL-B cells and induced inhibition of leukemic B cell growth in a synergistic manner. This combination also disrupts chemokine signaling, a key for CLL microenvironment interaction [48-52]. The studies in prostate cancer reported that SYK supports migration and growth of prostate cancer cells [53]. SYK also plays an important role in ovarian cancer as paclitaxel-resistant cells overexpress SYK. The ratio of phosphorylated SYK vs SYK was found to be positively associated with paclitaxel- resistance in ovarian cancer cells in vitro [54]. Furthermore, paclitaxel resistant SYK overexpressing ovarian cancer was targeted in pre-clinical models to show that use of chemical inhibitor against SYK could be useful to decelerate tumor activity [55].

A number of phase II trials are ongoing in chronic lymphocytic leukemia (CLL) using entospletinib [5658]. We investigated the effect of inhibiting SYK using entospletinib in ESCC cell line and a pre-clinical mouse model.
A

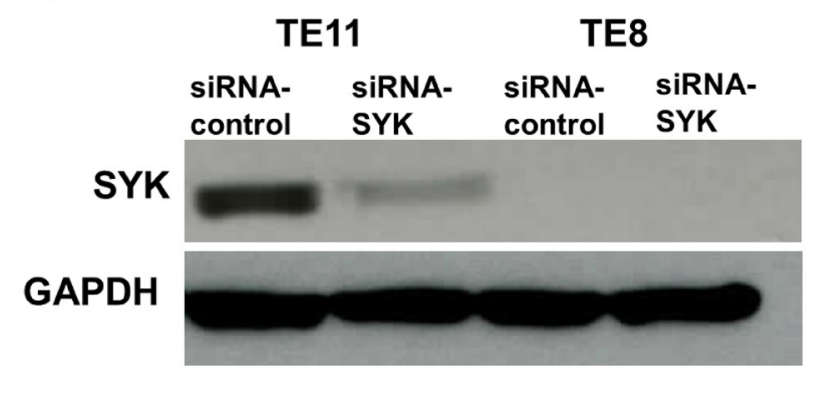

C

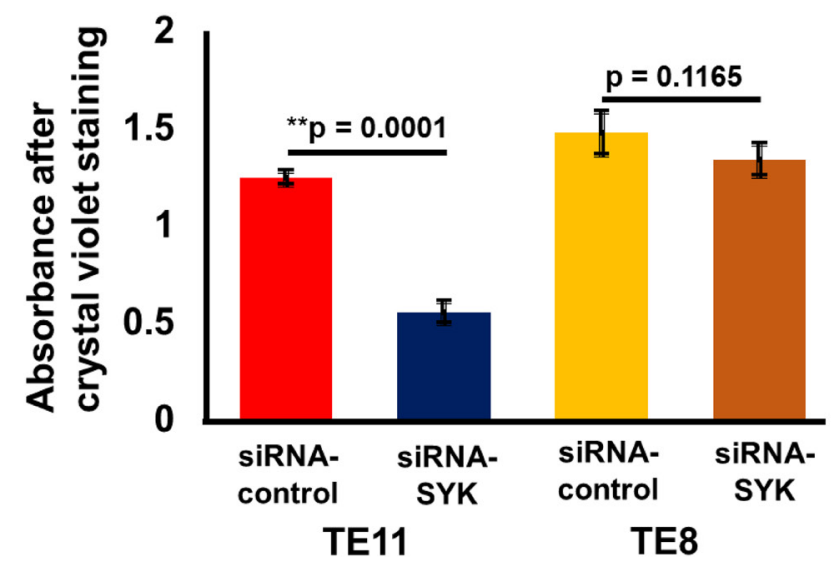

B

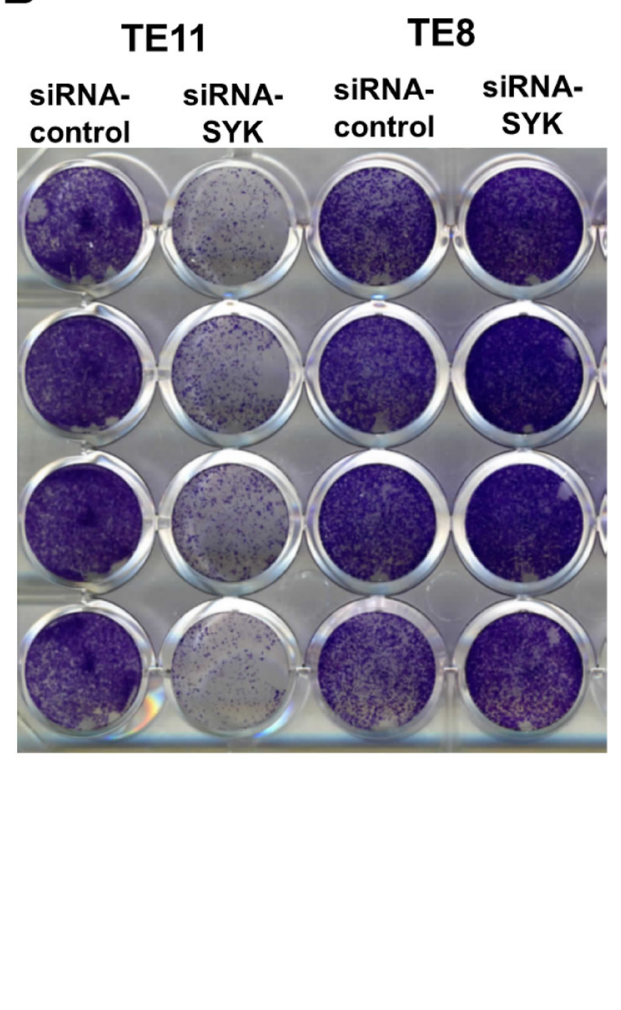

Figure 3: Effect of siRNA mediated knock down of SYK on cell proliferation, invasion/migration. (A) Western blot showing siRNA mediated knockdown of SYK expression in TE11 and TE8 cell lines. (B) Cell proliferation assays in TE11 and TE8 cell lines after knockdown of SYK. (C) Histogram showing crystal violet absorbance in TE11 and TE8 cell lines post siRNA mediated knockdown of SYK. 
siRNA based knockdown of SYK inhibits cell proliferation and cell invasion/migration in TE11 cells

The siRNA transfection studies were carried out in both SYK positive (TE11) and negative ESCC cell lines (TE8) (Figure 3A). Proliferation of TE11 cells was significantly reduced compared to scrambled siRNA controls. No effect on proliferation was observed in
TE8 (Figure 3B, 3C). siRNA based knockdown of SYK significantly decreased $(\mathrm{p}<0.002)$ invasion/migration capability of TE11 cells (Figure 4A, 4B). Similar data for inhibition of chemotaxis using siRNA based targeting of SYK has been observed in nasopharyngeal [59], endothelial [60] and aortic muscle cells [61]. We further evaluated efficacy of SYK selective inhibitor entospletinib that is already in phase II clinical trials for the treatment of hematological malignancies.
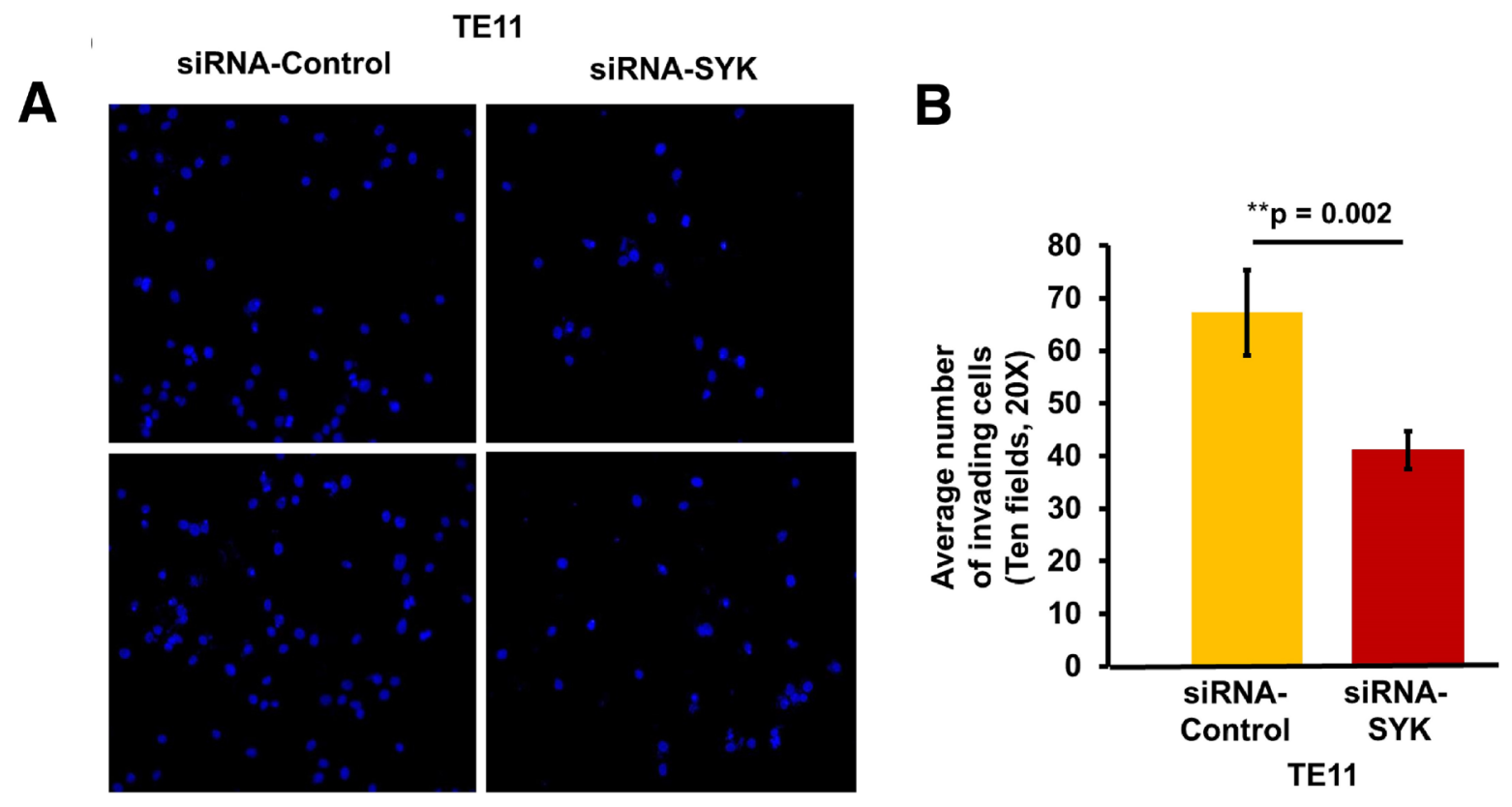

Two representative fields (20X magnification)
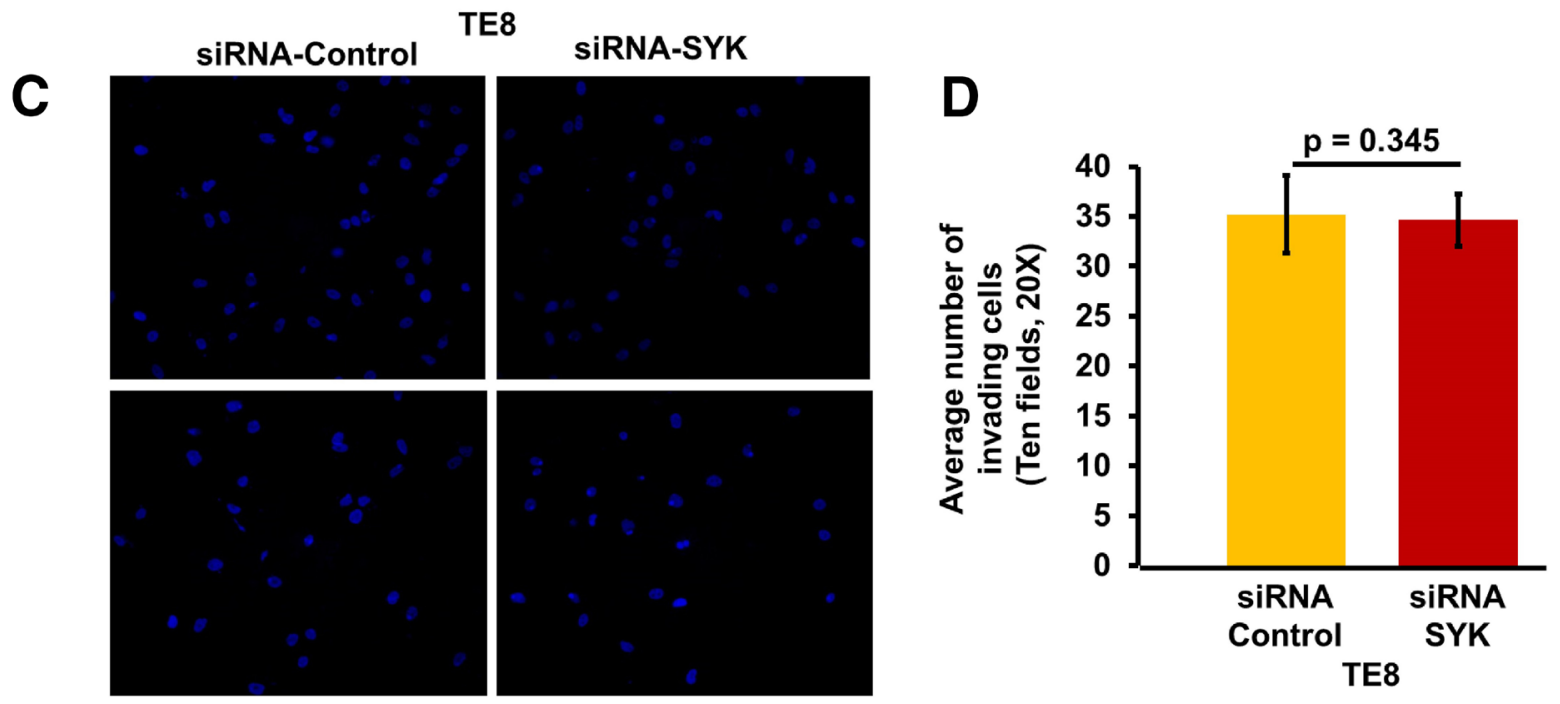

Two representative fields (20X magnification)

Figure 4: Effect of siRNA mediated knock down of SYK on invasion ability of TE11 and TE8 cell lines. (A) Representative image to show number of TE11 cells that invaded matrigel with and without knockdown of SYK. (B) Histogram showing relative difference in invasion of TE11 cells with and without knockdown of SYK. (C) Representative image to show number of TE8 cells that invaded matrigel with and without knockdown of SYK. (D) Histogram showing relative difference in invasion of TE8 cells with and without knockdown of SYK 


\section{SYK inhibition affects cell proliferation and growth rate in TE11 cells}

We treated TE11 (SYK positive) and TE8 (SYK negative) ESCC cell lines with $10 \mu \mathrm{M}$ entospletinib or vehicle (Figure 5A, 5B) in a crystal violet assay. Inhibition of SYK significantly reduced proliferation of TE11 cells. In addition, we carried out cell doubling time assay with cell counting and observed the same effect of the drug in TE11 cell line (Figure 5C). However, the drug had no effect on TE8 cell line (Figure 5D).

\section{Entospletinib inhibits in vivo tumor growth in TE11 mouse xenografts}

We tested all ESCC cell lines for their ability to grow as xenograft tumors in mice for in vivo pre-clinical evaluation of entospletinib. TE11 successfully formed tumors in mice. We xenografted TE11 cell line in 8 mice and randomized into two groups of four each and started treating the mice with entospletinib or vehicle after 10 days of subcutaneous injections. We observed a significant reduction in tumor size in the treated group compared to the control with tumor growth inhibition of $55 \%$ (Figure 6A). We observed significant reduction in tumor weight after necropsy in treatment group compared to control (Figure 6B, 6C). The expression of cell proliferation marker Ki-67 was reduced in tumors treated with entospletinib while there was increased expression of cleaved caspase 3 showing trigger of programmed cell death in the grafted tumors (Figure 6D). Immunostaining with CD34, a marker of vascular endothelial progenitor cells, showed decreased expression upon treatment with entospletinib (Figure 6D). Overall, our data suggest that SYK can be targeted using selective inhibitors like entospletinib in ESCC and these findings can be
A $\begin{array}{ccccc}\text { 1uM } & 2.5 u M & \text { 5uM } & \text { 10uM } & \text { DMSO } \\ \text { GS9973 } & \text { GS9973 GS9973 } & \text { GS9973 } & (0.8 \%)\end{array}$

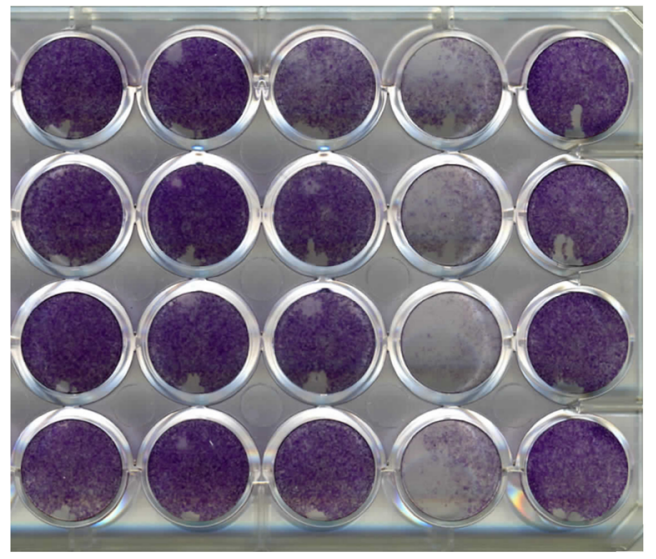

C

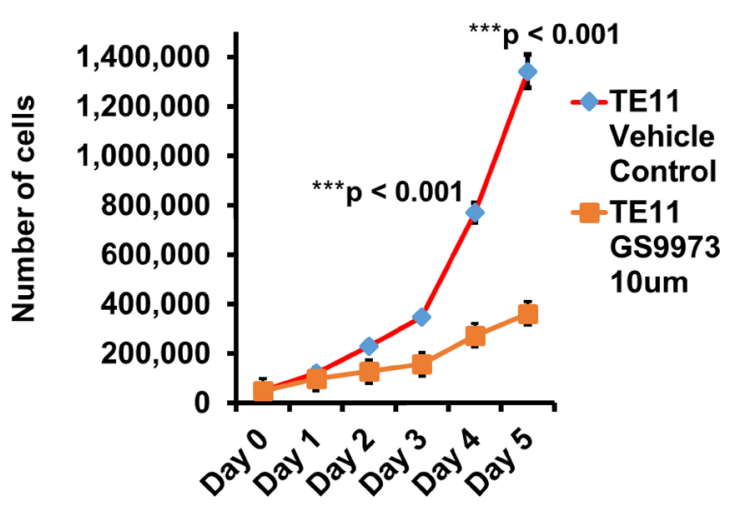

B

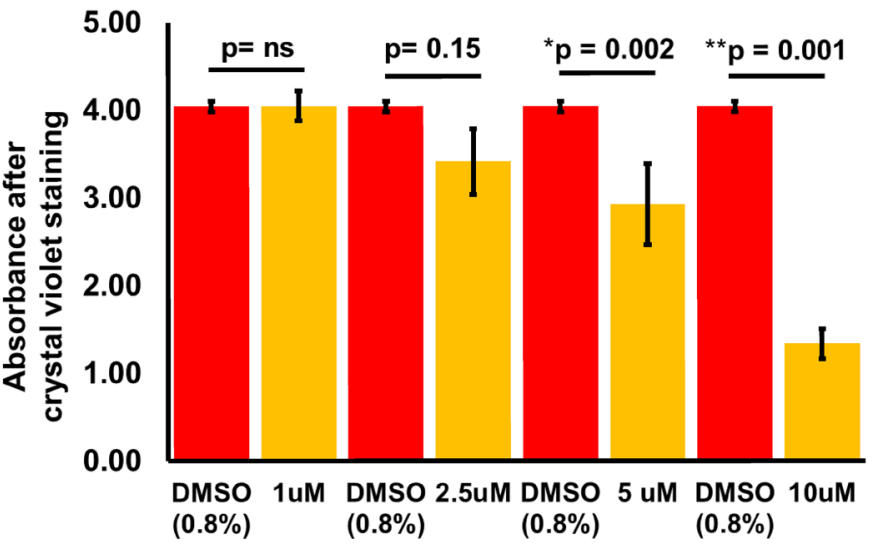

D

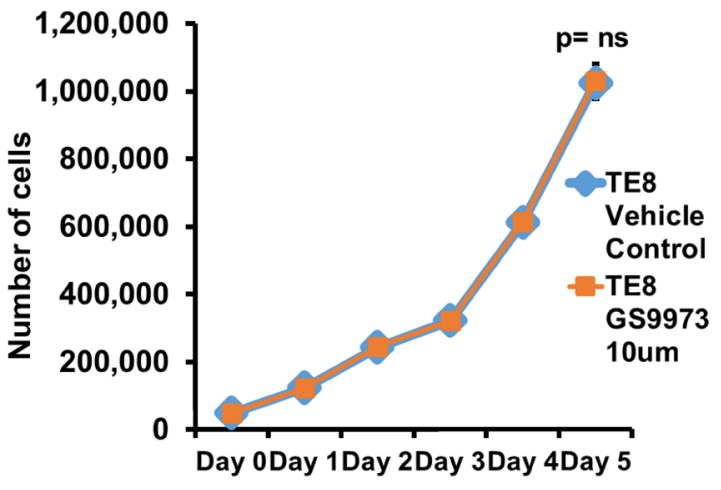

Figure 5: Effect of SYK inhibition using entospletinib/GS9973 on cell proliferation and cell doubling time of TE11 and TE8 cells. (A) Image showing crystal violet stained TE11 cells treated with various concentrations of entospletinib/GS9973. (B) Histogram showing relative absorbance after crystal violet staining of TE11 cells treated with various concentrations of entospletinib/ GS9973. (C) Growth rate of TE11 cell line treated with 10uM entospletinib/GS9973. (D) Growth rate of TE8 cell line treated with 10uM entospletinib/GS9973. 
extrapolated in cancers where SYK overexpression has been reported.

\section{DISCUSSION}

ESCC is one of the devastating cancers with poor survival rates. Chemotherapy and radiation remains mainstay for treating advanced cases of ESCC. Currently, targeted therapies are not available for treating ESCC. Whole genome/exome sequencing studies have been recently carried out to identify genetic anomalies associated with ESCC. Genes with activating mutations that are recurrent among ESCC tumors could be potentially targeted for therapeutic intervention. Similarly, gene expression and protein expression profiling studies have also been carried out to identify differentially expressed genes that could be potentially targeted.

Reverse phase protein arrays (RPPA) offer an unbiased way of monitoring large number of proteins from biospecimens. We employed this highthroughput methodology to monitor expression of 272 proteins across seven ESCC cell lines and a non- neoplastic esophageal epithelial cell line. The details of the antibodies as provided in the RPPA Array Core website of MD Anderson Cancer Centre is provided in Supplementary Table 3. We identified several proteins that were differentially expressed in ESCC cell lines compared to non-neoplastic esophageal epithelial cell line. Spleen associated tyrosine kinase (SYK) was found to be overexpressed in six out of seven cell lines that were investigated. Functional studies in esophageal cancer cell line showed siRNA mediated knock down of SYK inhibited proliferation, invasion/migration capability of cells. In addition, pharmacological inhibition of SYK in cell lines and mouse xenografts showed similar effects. Considering lack of effective targeted therapeutic agents to treat ESCC, these preclinical studies might prove valuable in prioritizing reliable candidates. SYK warrants further studies to determine its clinical utility as a potential target to treat ESCC. Our study provides a proof principle for further clinical investigations about the therapeutic potential of entospletinib in ESCC as the drug is already in clinical trials for other cancers.
A

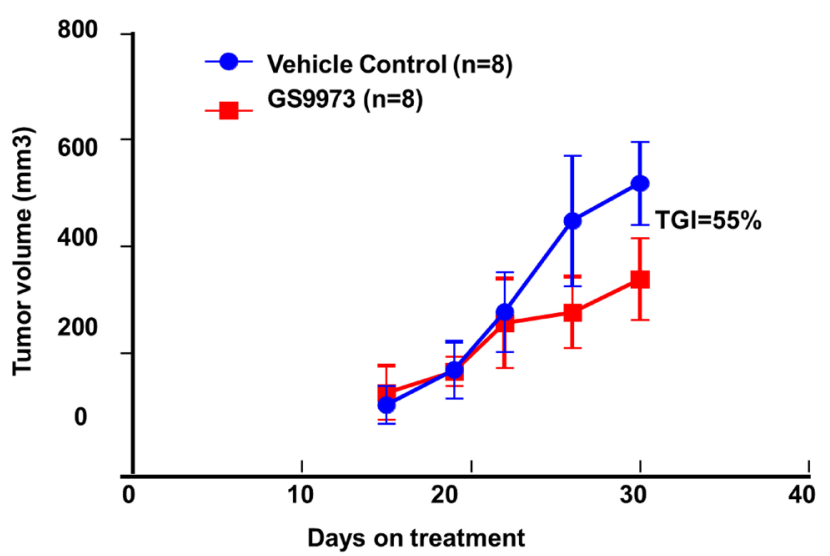

C

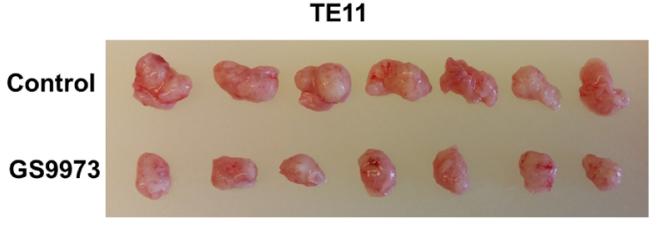

B
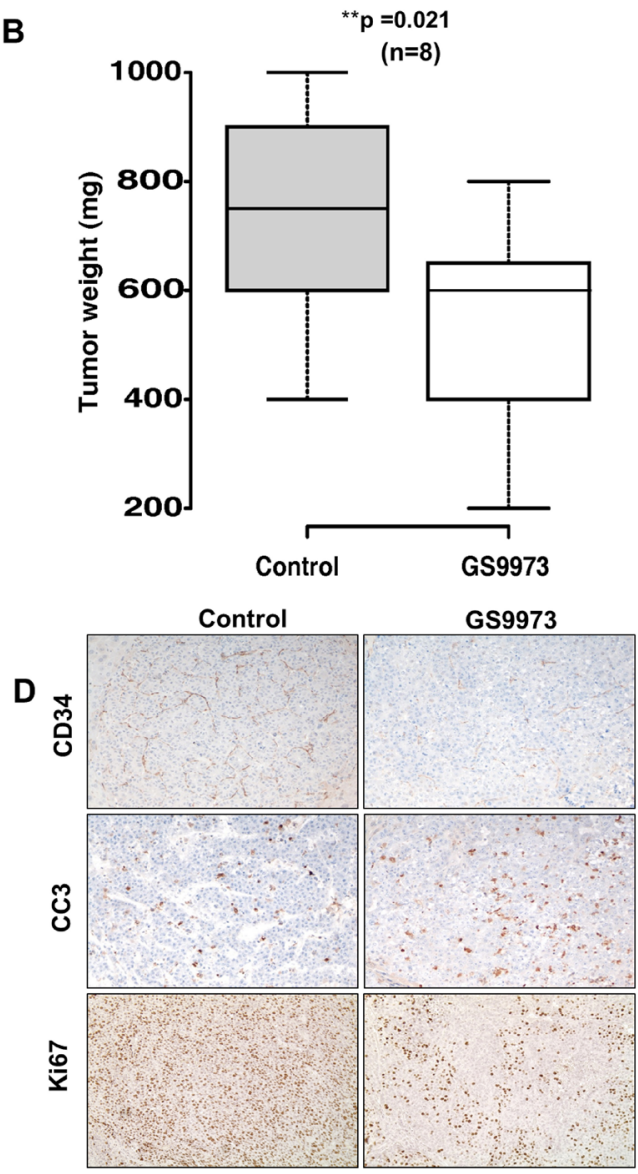

Figure 6: Effect of SYK inhibitor entospletinib/GS9973 on growth of subcutaneous xenograft of TE11 cell line. (A) Tumor growth in mice untreated or treated with SYK inhibitor entospletinib. (B) Box plot showing tumor weight in treatment and control group. (C) Representative tumors from four mice untreated or treated with entospletinib/GS9973. (D) Representative image of immunohistochemistry using anti CD34, Ki67 and cleaved caspase 3 on control and treated tumor tissue sections. 
Table 1: Details of esophageal cancer cell lines and non-neoplastic esophageal epithelial cell line used in the study

\begin{tabular}{lcc}
\hline & Name of Cell line & Differentiation characteristics of the cell lines \\
\hline $\mathbf{1}$ & TE1 & Well \\
$\mathbf{3}$ & TE2 & Poor \\
$\mathbf{4}$ & TE5 & Poor \\
$\mathbf{5}$ & TE8 & Moderate \\
$\mathbf{6}$ & TE10 & Well \\
$\mathbf{7}$ & TE11 & Moderate \\
$\mathbf{8}$ & TE15 & Well \\
\hline
\end{tabular}

Table 2: List of primers used for RT-PCR assay

\begin{tabular}{lcc}
\hline & RT-PCR primers & Amplicon Size (Bps) \\
\hline Primer & 5' Sequence 3' & 151 \\
\hline$G A P D H-\mathrm{FP}$ & TGGTCACCAGGGCTGCTT & \\
$G A P D H-\mathrm{RP}$ & AGCTTCCCGTTCTCAGCCTT & 514 \\
$S Y K-\mathrm{FP}$ & CATGTCAAGGATAAGAACATCATAGA & \\
$S Y K-\mathrm{RP}$ & AGTTCACCACGTCATAGTAGTAATT & \\
\hline
\end{tabular}

FP: forward primer; RP: reverse primer.

\section{MATERIALS AND METHODS}

\section{Cell lines and cell culture}

Esophageal squamous cell carcinoma cell lines TE1, TE2, TE5, TE8, TE10, TE11 and TE15 were grown in DMEM high glucose with $10 \%$ FBS supplement. The cell lines were kind gift from Dr. Anil K Rustgi, Division of Gastroenterology, University of Pennsylvania, USA. Non-neoplastic esophageal epithelial cell line Het-1A (purchased from ATCC) was grown in bronchial epithelial cell basal medium (BEBM) along with the required additives obtained from Lonza/Clonetics Corporation as a kit along with the media (Media Kit Catalog No. CC-3170). Cell lines were serum starved for 8 hours, washed in PBS three times and harvested in lysis buffer as described below. The details of ESCC and normal cell lines are provided in Table 1 . These cell lines were authenticated by short tandem repeat profiling at the Johns Hopkins Genetic Research Core Facility.

\section{Reverse phase protein array (RPPA)}

Proteins were extracted from all the cells in Lysis buffer (1\% Triton X-100, 50mM HEPES, pH 7.4, 150mM $\mathrm{NaCl}, 1.5 \mathrm{mM} \mathrm{MgCl} 2,1 \mathrm{mM}$ EGTA, 100mM NaF, 10mM Na pyrophosphate, $1 \mathrm{mM} \mathrm{Na} 3 \mathrm{VO} 4$, 10\% glycerol, protease and phosphatase inhibitors from Roche Applied Science Cat. 05056489001 and 04906837001). Protein quantity was measured using BCA protein assay and normalized in SDS-PAGE. Proteins from each cell line was mixed with 4X SDS sample buffer (40\% Glycerol, 8\% SDS, 0.25M Tris- HCL, $\mathrm{pH}$ 6.8) to a final concentration of $1 \mathrm{X}$ sample buffer and $1.5 \mathrm{ug} / \mathrm{ul}$ protein concentration. The lysates were boiled for five minutes and 40ul of the same were sent to RPPA core facility of MD Anderson Cancer Centre for further analysis in technical replicates. Remaining samples were frozen for future use in validation.

\section{Data acquisition and analysis}

All the samples were analyzed following published protocols [62]. In brief, cell lysates were two-fold-serial diluted for 5 dilutions (from undiluted to 1:16 dilution) and arrayed on nitrocellulose-coated slide in $11 \times 11$ format. Samples were probed with 272 antibodies by CSA amplification approach and visualized by DAB colorimetric reaction. The slides were scanned in flatbed scanner and the spots were quantified in Array Pro Analyzer. Relative protein levels for each sample were determined by interpolation of each dilution curves from the "standard curve" (supercurve) of the slide (antibody). The construction of supercurve was done using a script in R-environment [63]. These values (given as Log2 
values) are defined as Supercurve Log2 (Raw) value and shown in the page of "RawLog2". All the data points were normalized for protein loading and transformed to linear value, designated as "Normalized Linear" value. The linear value was used to compare differentially expressed proteins in ESCC cell lines compared to normal cell line (Supplementary Table 2). A detailed procedure is provided in Supplementary Method.

\section{Western blotting}

Cells from the procedure above were pelleted by centrifugation, washed twice with PBS, and lysed with modified RIPA buffer $(150 \mathrm{mM} \mathrm{NaCl}, 50 \mathrm{mM}$ Tris $\cdot \mathrm{HCl}$ $\mathrm{pH} 7.4,1 \% \mathrm{NP}-40,0.25 \%$ sodium deoxycholate, $1 \mathrm{mM}$ EDTA, $1 \mathrm{mM}$ sodium orthovanadate, $10 \mathrm{mM} \mathrm{NaF}, 10$ $\mathrm{mM}$ glycerophosphate, $5 \mathrm{mM}$ sodium pyrophosphate) containing $1 \%$ of human protease inhibitor cocktail (Sigma Aldrich) at $4^{\circ} \mathrm{C}$. The protein content of the whole cell lysates was quantified using a detergent compatible (DC) protein assay (Bio- Rad). Lysates in sample buffer comprised of $720 \mathrm{mM}$ 2-mercaptoethanol, $0.001 \%$ bromophenol blue, 2\% SDS, 10\% glycerol, $80 \mathrm{mM}$ Tris $\cdot \mathrm{HCl} \mathrm{pH} 6.8$ were denatured at $95^{\circ} \mathrm{C}$ for $5 \mathrm{~min}$. A sample containing $30 \mu \mathrm{g}$ of total protein was resolved on $4-20 \%$ Criterion Precast Gel (Bio-Rad) SDS-PAGE, followed by transfer using polyvinylidene difluoride (PVDF) membrane (Millipore). After blocking with 5\% bovine serum albumin (BSA) in TBST $(20 \mathrm{mM}$ Tris $\cdot \mathrm{HCl}$, $137 \mathrm{mM} \mathrm{NaCl}, 0.1 \%$ Tween-20 pH 7.6) for one hour at room temperature, the membrane was incubated with primary antibody overnight at $4^{\circ} \mathrm{C}$. The primary antibodies included a mouse anti-SYK antibody (clone 4D10, catalog \# SC-1240, Santa Cruz Biotechnology), and a rabbit antiGAPDH (clone 14C10, Catalog \# 2118, Cell Signaling Technology). All primary antibodies were used at 1:1000 dilution in TBST containing 5\% BSA. After washing three times with $10 \mathrm{ml}$ of TBST, the membranes were incubated with HRP-labeled anti-rabbit (sc-2030, Santa Cruz Biotechnology) or HRP-labeled anti-mouse (sc2031, Santa Cruz Biotechnology) secondary antibodies with a dilution of 1:5000 TBST containing 5\% BSA for one hour at room temperature. After washing twice with TBST, the membranes were incubated with horseradish peroxidase (HRP)-labeled anti-rabbit (sc-2030, Santa Cruz Biotechnology) or HRP-labeled anti-mouse (sc2031, Santa Cruz Biotechnology) secondary antibodies with a dilution of 1:5000 for $1 \mathrm{~h}$ at room temperature. Protein- antibody complex signals were detected by exposing the X-ray films after treatment with enhanced chemiluminescence (ECL) kit (Pierce Thermo Scientific).

\section{siRNA transfection of TE11 and TE8 cells}

TE11 and TE cell lines were transiently transfected using siRNA-SYK and siRNA scrambled control-using lipofectamine RNAiMax by following the manufacturer's protocol (Catalog \# 13778075, ThermoFisher). We performed siRNA-based knockdown of SYK in TE11 and TE8 cell lines. The expression of SYK was transiently knocked down using $25 \mathrm{pmol}$ of ON-TARGETplus Human SYK smart pool siRNA (Catalog \# L- 00317600-0010; Dharmacon). Allstars negative control siRNA was purchased from Qiagen (Catalog \# 1027281), it was used for siRNA-scrambled control transfection at a final concentration of $25 \mathrm{pM}$. The day prior to transfection, cells were seeded at $60 \%$ confluence in six well plates and siRNA transfection was carried out next day, the knockdown of the target was checked by western blot after 36 hours post-transfection.

\section{Cell proliferation and crystal violet staining}

Cells were trypsinized after 36 hours of siRNA transfection and 5000 cells were seeded onto four wells of 24 well plates in triplicate and stained with $0.5 \%$ crystal violet. Cells were then fixed with $0.1 \%$ acetic acid for $5 \mathrm{~min}$ and stained with $0.5 \%$ crystal violet dye (in methanol:deionized water, 1:5) for $10 \mathrm{~min}$. The excess crystal violet dye was removed by five washes in deionized water on a shaker (each was for $10 \mathrm{~min}$ ) and the culture plates were dried overnight. The crystal violet dye was released from cells by incubation with $1 \%$ sodium dodecyl sulfate (SDS) for $6 \mathrm{~h}$ before optical density (OD)595 nm measurement. Similarly, cells were seeded at a density of 5000 cells per well in 24 well plates and treated with entospletinib at different concentrations (1 $\mu \mathrm{M}, 2.5 \mu \mathrm{M}, 5 \mu \mathrm{M}$ and $10 \mu \mathrm{M})$ for five days. Crystal violet assays were performed to determine the effective dose of entospletinib on both cell lines for cell doubling time assay.

\section{Cell doubling time assay}

A total of $5 \times 10^{4}$ cells (TE11 and TE8) were seeded in duplicate in a six well plate. entospletinib $(10 \mu \mathrm{M})$ treatment and vehicle control $(0.8 \%$ DMSO $)$ were started from Day 0 (next day of plating) and continued till Day 5. The cells were counted using $\mathrm{Z}^{\mathrm{TM}}$ Series COULTER COUNTER $^{\circledR}$ for next six days with or without SYK inhibitor treatment.

\section{Invasion/migration assays and imaging}

Post 36 hours of siRNA transfection, cells were trypsinized and $5 \times 10^{4}$ cells seeded onto Biocoat matrigel invasion chambers (catalog \# 354480, BD Biosciences) in high glucose DMEM containing 2\% FBS. DMEM high glucose medium with $10 \%$ FBS was added in the lower chamber as chemo attractant. The cells were allowed to invade the matrigel membrane overnight. The membranes were stained with DAPI (Invitrogen) after carefully removing the cells from the inner side and the number of cells that had invaded the matrigel and membrane was counted in 10 randomly selected 
fields at 20X magnification under fluorescence microscope using blue/cyan filter. Cells were counted using ImageJ and average number of cells in siRNA- control and siRNA-SYK in TE11 and TE8 lines were calculated separately to evaluate the differences in invasion between siRNA-control and siRNASYK transfected TE11 and TE8 cells.

\section{RT-PCR analyses in ESCC and normal esophageal cell lines}

A total of $5 \times 10^{6}$ cells were taken from TE8, TE-11 and Het-1A cell lines. Total RNA was isolated from all the cell lines and cDNA library was prepared. PCR reaction was performed in $20 \mu \mathrm{l}$ reaction volume as described previously. PCR conditions $-94^{\circ} \mathrm{C}$ for $3 \mathrm{~min} ; 35$ cycles of $94^{\circ} \mathrm{C}$ for $30 \mathrm{~s}, 55-60^{\circ} \mathrm{C}$ (annealing temperature: $56^{\circ} \mathrm{C}$ for $G A P D H, 53^{\circ} \mathrm{C}$ for $\mathrm{SYK}$, for $30 \mathrm{~s}$, and $72^{\circ} \mathrm{C}$ for $1 \mathrm{~min}$; followed by $72^{\circ} \mathrm{C}$ for $5 \mathrm{~min}$. PCR products were separated on a $2 \%$ agarose gel and stained with ethidium bromide. Details of the primers used for RT-PCR are provided in Table 2.

\section{Mouse xenograft studies with SYK inhibitor entospletinib}

All the procedures involved in animal work was approved by the JHMI institutional animal care and use committee and were performed in accordance with the IACUC. All the seven cancer cell lines were tested for their ability to graft tumors in NSG mice (NOD.CgPrkdc $\left.c^{\text {scid }} I l 2 \mathrm{rg}^{\text {tm } l W j l} / \mathrm{SzJ}\right)$. The characteristics of these mice combine the features of the NOD/ShiLtJ background, the severe combined immune deficiency mutation (SCID) and IL2 receptor gamma chain deficiency that results in lack of mature T, B or functional NK cells, and are deficient in cytokine signaling in NSG mice leading to better engraftment of cells of interest. Only TE11 cell line formed tumors after subcutaneous injection of 2 million cells per site on both flanks of mice. To evaluate the therapeutic potential of targeting SYK with entospletinib, TE11 cells were injected subcutaneously into flanks of NOD-SCID mice. Tumor growth was measured twice a week and the tumor volume was estimated as [Tumor Volume $=($ Breadth $x$ Breadth $) \times L$ ength $/ 2]$. Once the tumors attained desired volume $(\sim 80 \mathrm{~mm} 3)$, animals were segregated into treatment $(n=4)$ and control $(n=4)$ groups. Each group was treated using subcutaneous injection of entospletinib at $10-\mathrm{mg} / \mathrm{Kg}$-body weight thrice a week. The animals were followed for 30 days and tumor volumes were recorded. Body weight was measured during treatment process to see if treatment induced toxicity leads to weight loss in animals.

\section{Immunohistochemistry}

The xenograft tumors were fixed in $10 \%$ buffered formalin (Formalin, Buffered, 10\% (Phosphate Buffer/
Certified), Fisher Chemical, USA) and paraffin blocks and tissue sections were prepared using standard protocols. Immunohistochemistry on the subcutaneous xenograft tumor sections were carried out using an antiCD34 antibody from Abcam (ab8536, mouse monoclonal antibody) at a dilution of 1:200. Rabbit monoclonal antibody against cleaved caspase-3 ((Asp175) (D3E9) CST \#9579) from Cell Signalling Technology was used at 1:200 dilution for immunostaining. Rabbit monoclonal anti- Ki-67 Antibody (MA5-14520) from ThermoFisher Scientific, USA was used to immunostain proliferating cells. The Poly-HRP anti-Rabbit IHC Detection Systems (Leica Biosystems, USA) and DAB chromogen system (Vector Labs, USA) were used for detection of signals. Counterstaining was carried out with Hematoxylin QS (H3404, Vector Labs, USA) and quenched in Scotts buffer (Catalogue, 3802900, Leica Biosystems, USA).

\section{Statistical analysis}

Statistical analysis was done using GraphPad Prism software (v. 5.0c; San Diego, CA). Statistical significance was determined by using paired or unpaired Student's $t$ test or one-way ANOVA followed by Bonferroni correction's multiple comparisons test. Statistical differences for the mean values are indicated as follows: ${ }^{*}, p<0.05 ;{ }^{* *}, p<$ $0.01 ;{ }^{* * *}, p<0.001$; and ${ }^{* * * *}, p<0.0001$. Unless indicated, data are presented as the mean $\pm \mathrm{SEM}$.

\section{Abbreviations}

BEBM: bronchial epithelial cell basal medium; EAD: esophageal adenocarcinoma; ECL: enhanced chemiluminescence; ESCC: esophageal squamous cell carcinoma; HCC: hepatocellular carcinoma; HNSCC: head and neck squamous cell carcinoma; HRP: horseradish peroxidase; iTRAQ: isobaric tags for relative and absolute quantitation; MRM: multiple reaction monitoring; OD: optical density; PTMs: post-translational modifications; PTM; RPPA: reverse phase protein array; TMT: Tandem mass tags; SILAC: stable isotope labeling with amino acids in cell culture; SDS: sodium dodecyl sulfate; SYK: spleen tyrosine kinase.

\section{Author contributions}

MAB, HG, MKK and VNP carried out experiments and data analysis. XW and RVJ carried out data analysis and wrote part of the manuscript. MAB, MKK, AP and HG wrote the manuscript. AP and HG supervised the study and finalized the manuscript.

\section{ACKNOWLEDGMENTS}

The authors thank the Department of Biotechnology (DBT), Government of India, for research support to the Institute of Bioinformatics, Bangalore. This work 
was supported by NIH grants (R01CA184165 and P50NS038377) to Dr. Akhilesh Pandey.Dr. Rekha V. Kumar is supported by DBT grant (DBT/CSH/ GIA/1583/2010-2011). Dr. Harsha Gowda is a Wellcome Trust/DBT India Alliance Early Career Fellow.

\section{CONFLICTS OF INTEREST}

The authors declare no conflicts of interest.

\section{FUNDING}

This study is partially supported by research grants from Wellcome Trust/DBT India (Grant number: 500089/Z/09/Z) to Dr. Harsha Gowda and support from the NIH to Dr. Akhilesh Pandey.

\section{REFERENCES}

1. Kashyap MK, Marimuthu A, Kishore CJ, Peri S, Keerthikumar S, Prasad TS, Mahmood R, Rao S, Ranganathan P, Sanjeeviah RC, Vijayakumar M, Kumar $\mathrm{KV}$, Montgomery EA, et al. Genomewide mRNA profiling of esophageal squamous cell carcinoma for identification of cancer biomarkers. Cancer Biol Ther. 2009; 8:36-46.

2. Jemal A, Bray F, Center MM, Ferlay J, Ward E, Forman D. Global cancer statistics. CA Cancer J Clin. 2011; 61:69-90.

3. Enzinger PC, Mayer RJ. Esophageal cancer. N Engl J Med. 2003; 349:2241-2252.

4. Kashyap MK, Harsha HC, Renuse S, Pawar H, Sahasrabuddhe NA, Kim MS, Marimuthu A, Keerthikumar S, Muthusamy B, Kandasamy K, Subbannayya Y, Prasad TS, Mahmood R, et al. SILAC-based quantitative proteomic approach to identify potential biomarkers from the esophageal squamous cell carcinoma secretome. Cancer Biol Ther. 2010; 10:796-810.

5. Andrici J, Eslick GD. Mate consumption and the risk of esophageal squamous cell carcinoma: a meta-analysis. Dis Esophagus. 2013; 26:807-816.

6. Amani F, Ahari SS, Akhghari L. Epidemiology of esophageal cancer in ardabil province during 2003-2011. Asian Pac J Cancer Prev. 2013; 14:4177-4180.

7. Jung SH, Gombojav B, Park EC, Nam CM, Ohrr H, Won JU. Population based study of the association between binge drinking and mortality from cancer of oropharynx and esophagus in Korean men: the Kangwha cohort study. Asian Pac J Cancer Prev. 2014; 15:3675-3679.

8. Pawar H, Kashyap MK, Sahasrabuddhe NA, Renuse S, Harsha HC, Kumar P, Sharma J, Kandasamy K, Marimuthu A, Nair B, Rajagopalan S, Maharudraiah J, Premalatha CS. Quantitative tissue proteomics of esophageal squamous cell carcinoma for novel biomarker discovery. Cancer Biol Ther. 2011; 12:510-522.

9. Qi YJ, Chao WX, Chiu JF. An overview of esophageal squamous cell carcinoma proteomics. J Proteomics. 2012; 75:3129-3137.
10. Negm OH, Muftah AA, Aleskandarany MA, Hamed MR, Ahmad DA, Nolan CC, Diez-Rodriguez M, Tighe PJ, Ellis IO, Rakha EA, Green AR. Clinical utility of reverse phase protein array for molecular classification of breast cancer. Breast Cancer Res Treat. 2016; 155:25-35.

11. Wiegand KC, Hennessy BT, Leung S, Wang Y, Ju Z, McGahren M, Kalloger SE, Finlayson S, Stemke-Hale K, Lu Y, Zhang F, Anglesio MS, Gilks B, et al. A functional proteogenomic analysis of endometrioid and clear cell carcinomas using reverse phase protein array and mutation analysis: protein expression is histotype-specific and loss of ARID1A/BAF250a is associated with AKT phosphorylation. BMC Cancer. 2014; 14:120.

12. Li H, Wheeler S, Park Y, Ju Z, Thomas SM, Fichera M, Egloff AM, Lui VW, Duvvuri U, Bauman JE, Mills GB, Grandis JR. proteomic characterization of head and neck cancer patient-derived xenografts. Mol Cancer Res. 2016; 14:278-286.

13. Masuda M, Chen WY, Miyanaga A, Nakamura Y, Kawasaki K, Sakuma T, Ono M, Chen CL, Honda K, Yamada T. Alternative mammalian target of rapamycin (mTOR) signal activation in sorafenib-resistant hepatocellular carcinoma cells revealed by array-based pathway profiling. Mol Cell Proteomics. 2014; 13:1429-1438.

14. Ummanni R, Mannsperger HA, Sonntag J, Oswald M, Sharma AK, Konig R, Korf U. Evaluation of reverse phase protein array (RPPA)-based pathway-activation profiling in 84 non-small cell lung cancer (NSCLC) cell lines as platform for cancer proteomics and biomarker discovery. Biochim Biophys Acta. 2014; 1844:950-959.

15. Malinowsky $\mathrm{K}$, Wolff $\mathrm{C}$, Schott C, Becker KF. Characterization of signalling pathways by reverse phase protein arrays. Methods Mol Biol. 2013; 1049:285-299.

16. Nishizuka S, Chen ST, Gwadry FG, Alexander J, Major SM, Scherf U, Reinhold WC, Waltham M, Charboneau L, Young L, Bussey KJ, Kim S, Lababidi S, et al. Diagnostic markers that distinguish colon and ovarian adenocarcinomas: identification by genomic, proteomic, and tissue array profiling. Cancer Res. 2003; 63:5243-5250.

17. Hehlgans S, Cordes N. Caveolin-1: an essential modulator of cancer cell radio-and chemoresistance. Am J Cancer Res. 2011; 1:521-530.

18. Chatterjee M, Ben-Josef E, Thomas DG, Morgan MA, Zalupski MM, Khan G, Andrew Robinson C, Griffith KA, Chen CS, Ludwig T, Bekaii-Saab T, Chakravarti A, Williams TM. Caveolin-1 is associated with tumor progression and confers a multi-modality resistance phenotype in pancreatic cancer. Sci Rep. 2015; 5:10867.

19. Wiechen K, Diatchenko L, Agoulnik A, Scharff KM, Schober H, Arlt K, Zhumabayeva B, Siebert PD, Dietel M, Schafer R, Sers C. Caveolin-1 is down-regulated in human ovarian carcinoma and acts as a candidate tumor suppressor gene. Am J Pathol. 2001; 159:1635-1643.

20. Bender FC, Reymond MA, Bron C, Quest AF. Caveolin-1 levels are down-regulated in human colon tumors, and 
ectopic expression of caveolin-1 in colon carcinoma cell lines reduces cell tumorigenicity. Cancer Res. 2000; 60:5870-5878.

21. Lee SW, Reimer CL, Oh P, Campbell DB, Schnitzer JE. Tumor cell growth inhibition by caveolin re-expression in human breast cancer cells. Oncogene. 1998; 16:1391-1397.

22. Sugie S, Mukai S, Tsukino H, Toda Y, Yamauchi T, Nishikata I, Kuroda Y, Morishita K, Kamoto T. Increased plasma caveolin-1 levels are associated with progression of prostate cancer among Japanese men. Anticancer Res. 2013; 33:1893-1897.

23. Yang G, Goltsov AA, Ren C, Kurosaka S, Edamura K, Logothetis R, DeMayo FJ, Troncoso P, Blando J, DiGiovanni J, Thompson TC. Caveolin-1 upregulation contributes to c-Myc-induced high-grade prostatic intraepithelial neoplasia and prostate cancer. Mol Cancer Res. 2012; 10:218-229.

24. Ando T, Ishiguro H, Kimura M, Mitsui A, Mori Y, Sugito N, Tomoda K, Mori R, Harada K, Katada T, Ogawa R, Fujii Y, Kuwabara Y. The overexpression of caveolin-1 and caveolin-2 correlates with a poor prognosis and tumor progression in esophageal squamous cell carcinoma. Oncol Rep. 2007; 18:601-609.

25. Kato K, Hida Y, Miyamoto M, Hashida H, Shinohara T, Itoh T, Okushiba S, Kondo S, Katoh H. Overexpression of caveolin-1 in esophageal squamous cell carcinoma correlates with lymph node metastasis and pathologic stage. Cancer. 2002; 94:929-933.

26. Zhang S, Cao W, Yue M, Zheng N, Hu T, Yang S, Dong Z, Lu S, Mo S. Caveolin-1 affects tumor drug resistance in esophageal squamous cell carcinoma by regulating expressions of P-gp and MRP1. Tumour Biol. 2016; 37:9189-9196.

27. Al Moustafa AE, Alaoui-Jamali MA, Batist G, HernandezPerez M, Serruya C, Alpert L, Black MJ, Sladek R, Foulkes WD. Identification of genes associated with head and neck carcinogenesis by cDNA microarray comparison between matched primary normal epithelial and squamous carcinoma cells. Oncogene. 2002; 21:2634-2640.

28. Kominsky SL, Argani P, Korz D, Evron E, Raman V, Garrett E, Rein A, Sauter G, Kallioniemi OP, Sukumar S. Loss of the tight junction protein claudin-7 correlates with histological grade in both ductal carcinoma in situ and invasive ductal carcinoma of the breast. Oncogene. 2003; 22:2021-2033.

29. Dahiya N, Becker KG, Wood WH 3rd, Zhang Y, Morin PJ. Claudin-7 is frequently overexpressed in ovarian cancer and promotes invasion. PLoS One. 2011; 6:e22119.

30. Johnson AH, Frierson HF, Zaika A, Powell SM, Roche J, Crowe S, Moskaluk CA, El-Rifai W. Expression of tightjunction protein claudin-7 is an early event in gastric tumorigenesis. Am J Pathol. 2005; 167:577-584.

31. Lioni M, Brafford P, Andl C, Rustgi A, El-Deiry W, Herlyn M, Smalley KS. Dysregulation of claudin-7 leads to loss of E-cadherin expression and the increased invasion of esophageal squamous cell carcinoma cells. Am J Pathol. 2007; 170:709-721.

32. Usami Y, Chiba H, Nakayama F, Ueda J, Matsuda Y, Sawada N, Komori T, Ito A, Yokozaki H. Reduced expression of claudin-7 correlates with invasion and metastasis in squamous cell carcinoma of the esophagus. Hum Pathol. 2006; 37:569-577.

33. Keshava Prasad TS, Goel R, Kandasamy K, Keerthikumar S, Kumar S, Mathivanan S, Telikicherla D, Raju R, Shafreen B, Venugopal A, Balakrishnan L, Marimuthu A, Banerjee S, et al. Human protein reference database - 2009 update. Nucleic Acids Res. 2009; 37e):D767-772.

34. Prinos P, Garneau D, Lucier JF, Gendron D, Couture S, Boivin M, Brosseau JP, Lapointe E, Thibault P, Durand M, Tremblay K, Gervais-Bird J, Nwilati H. Alternative splicing of SYK regulates mitosis and cell survival. Nat Struct Mol Biol. 2011; 18:673-679.

35. Jin Z, Wang L, Cao Z, Cheng Y, Gao Y, Feng X, Chen S, Yu H, Wu W, Zhao Z, Dong M, Zhang X, Liu J, et al. Temporal evolution in caveolin 1 methylation levels during human esophageal carcinogenesis. BMC Cancer. 2014; 14:345.

36. Mocsai A, Ruland J, Tybulewicz VL. The SYK tyrosine kinase: a crucial player in diverse biological functions. Nat Rev Immunol. 2010; 10:387-402.

37. Uckun FM, Qazi S. Spleen tyrosine kinase as a molecular target for treatment of leukemias and lymphomas. Expert Rev Anticancer Ther. 2010; 10:1407-1418.

38. Uckun FM, Qazi S. SYK as a new therapeutic target in B-cell precursor acute lymphoblastic leukemia. J Cancer Ther. 2014; 5:124-131.

39. Kipps TJ. The B-cell receptor and ZAP-70 in chronic lymphocytic leukemia. Best Pract Res Clin Haematol. 2007; 20:415-424.

40. Stevenson FK, Caligaris-Cappio F. Chronic lymphocytic leukemia: revelations from the B-cell receptor. Blood. 2004; 103:4389-4395.

41. Friedberg JW, Sharman J, Sweetenham J, Johnston PB, Vose JM, Lacasce A, Schaefer-Cutillo J, De Vos S, Sinha R, Leonard JP, Cripe LD, Gregory SA, Sterba MP, et al. Inhibition of Syk with fostamatinib disodium has significant clinical activity in non-Hodgkin lymphoma and chronic lymphocytic leukemia. Blood. 2010; 115:2578-2585.

42. Luangdilok S, Box C, Patterson L, Court W, Harrington K, Pitkin L, Rhys-Evans P, O-charoenrat P, Eccles S. Syk tyrosine kinase is linked to cell motility and progression in squamous cell carcinomas of the head and neck. Cancer Res. 2007; 67:7907-7916.

43. Muellner MK, Mair B, Ibrahim Y, Kerzendorfer C, Lechtermann H, Trefzer C, Klepsch F, Muller AC, Leitner E, Macho-Maschler S, Superti-Furga G, Bennett KL, Baselga J, et al. Targeting a cell state common to triplenegative breast cancers. Mol Syst Biol. 2015; 11:789.

44. Layton T, Stalens C, Gunderson F, Goodison S, Silletti S. Syk tyrosine kinase acts as a pancreatic adenocarcinoma 
tumor suppressor by regulating cellular growth and invasion. Am J Pathol. 2009; 175:2625-2636.

45. Krisenko MO, Geahlen RL. Calling in SYK: SYK's dual role as a tumor promoter and tumor suppressor in cancer. Biochim Biophys Acta. 2015; 1853:254-263.

46. Perova T, Grandal I, Nutter LM, Papp E, Matei IR, Beyene J, Kowalski PE, Hitzler JK, Minden MD, Guidos CJ, Danska JS. Therapeutic potential of spleen tyrosine kinase inhibition for treating high-risk precursor B cell acute lymphoblastic leukemia. Sci Transl Med. 2014; 6:236ra262.

47. Porcu P, Flinn I, Kahl BS, Horwitz SM, Oki Y, Byrd J, Sweeney J, Allen K, Faia K, Ni M, Stern HM, Kelly P, O'Brien S. Clinical activity of Duvelisib (IPI-145), a phosphoinositide- 3-kinsase- $\partial / \gamma$ inhibitor in patients previously treated with ibrutinib. Blood. 2014; 123:3335.

48. Burke RT, Meadows S, Loriaux MM, Currie KS, Mitchell SA, Maciejewski P, Clarke AS, Dipaolo JA, Druker BJ, Lannutti BJ, Spurgeon SE. A potential therapeutic strategy for chronic lymphocytic leukemia by combining Idelalisib and GS-9973, a novel spleen tyrosine kinase (Syk) inhibitor. Oncotarget. 2014; 5:908-915. https://doi.org/10.18632/ oncotarget. 1484 .

49. ten Hacken E, Burger JA. Molecular pathways: targeting the microenvironment in chronic lymphocytic leukemia-focus on the B-cell receptor. Clin Cancer Res. 2014; 20:548-556.

50. Han TT, Fan L, Li JY, Xu W. Role of chemokines and their receptors in chronic lymphocytic leukemia: function in microenvironment and targeted therapy. Cancer Biol Ther. 2014; 15:3-9.

51. Geahlen RL. Getting Syk: spleen tyrosine kinase as a therapeutic target. Trends Pharmacol Sci. 2014; 35:414-422.

52. Choi MY, Kashyap MK, Kumar D. The chronic lymphocytic leukemia microenvironment: beyond the B-cell receptor. Best Pract Res Clin Haematol. 2016; 29:40-53.

53. Ghotra VP, He S, van der Horst G, Nijhoff S, de Bont H, Lekkerkerker A, Janssen R, Jenster G, van Leenders GJ, Hoogland AM, Verhoef EI, Baranski Z, Xiong J, et al. SYK is a candidate kinase target for the treatment of advanced prostate cancer. Cancer Res. 2015; 75:230-240.

54. Wei W, Birrer MJ. Spleen tyrosine kinase confers paclitaxel resistance in ovarian cancer. Cancer Cell. 2015; 28:7-9.

55. Yu Y, Gaillard S, Phillip JM, Huang TC, Pinto SM, Tessarollo NG, Zhang Z, Pandey A, Wirtz D, Ayhan A, Davidson B, Wang TL, Shih IeM. Inhibition of spleen tyrosine kinase potentiates paclitaxel-induced cytotoxicity in ovarian cancer cells by stabilizing microtubules. Cancer Cell. 2015; 28:82-96.

56. Sharman J, Hawkins M, Kolibaba K, Boxer M, Klein L, Wu M, Hu J, Abella S, Yasenchak C. An open-label phase 2 trial of entospletinib (GS-9973), a selective spleen tyrosine kinase inhibitor, in chronic lymphocytic leukemia. Blood. 2015; 125:2336-2343.

57. Barr PM, Saylors GB, Spurgeon SE, Cheson BD, Greenwald DR, O'Brien SM, Liem AK, McIntyre RE, Joshi A, Abella-Dominicis E, Hawkins MJ, Reddy A, Di Paolo J, et al. Phase 2 study of idelalisib and entospletinib: pneumonitis limits combination therapy in relapsed refractory CLL and NHL. Blood. 2016; 127:2411-2415.

58. Chapuy B, Cheng H, Watahiki A, Ducar MD, Tan Y, Chen L, Roemer MG, Ouyang J, Christie AL, Zhang L, Gusenleitner D, Abo RP, Farinha P, et al. Diffuse large B-cell lymphoma patient-derived xenograft models capture the molecular and biologic heterogeneity of the disease. Blood. 2016; 127:2203-2213.

59. Lu J, Lin WH, Chen SY, Longnecker R, Tsai SC, Chen CL, Tsai CH. Syk tyrosine kinase mediates Epstein-Barr virus latent membrane protein $2 \mathrm{~A}$-induced cell migration in epithelial cells. J Biol Chem. 2006; 281:8806-8814.

60. Inatome R, Yanagi S, Takano T, Yamamura H. A critical role for Syk in endothelial cell proliferation and migration. Biochem Biophys Res Commun. 2001; 286:195-199.

61. Lee CK, Lee HM, Kim HJ, Park HJ, Won KJ, Roh HY, Choi WS, Jeon BH, Park TK, Kim B. Syk contributes to PDGFBB-mediated migration of rat aortic smooth muscle cells via MAPK pathways. Cardiovasc Res. 2007; 74:159-168.

62. Tibes R, Qiu Y, Lu Y, Hennessy B, Andreeff M, Mills GB, Kornblau SM. Reverse phase protein array: validation of a novel proteomic technology and utility for analysis of primary leukemia specimens and hematopoietic stem cells. Mol Cancer Ther. 2006; 5:2512-2521.

63. Akbani R, Becker KF, Carragher N, Goldstein T, de Koning L, Korf U, Liotta L, Mills GB, Nishizuka SS, Pawlak M, Petricoin EF 3rd, Pollard HB, Serrels B, et al. Realizing the promise of reverse phase protein arrays for clinical, translational, and basic research: a workshop report: the RPPA (Reverse Phase Protein Array) society. Mol Cell Proteomics. 2014; 13:1625-1643. 